\title{
Old-Fashioned in Order to be Modern: Seghelijn van Iherusalem and its Woodcuts
}

\begin{abstract}
Seghelijn van Jherusalem is a fourteenth-century verse narrative, extant in one manuscript and six printed editions. Since the 1983 publication of Ingrid van de Wijer's doctoral thesis on the text, interest has increased and Seghelijn has been the subject of several studies. These investigations always concern the text, whereas the woodcuts in the printed editions have received little attention. In this contribution these woodcuts and especially the title illustrations are the main focus of interest. The first edition appeared in Delft (1483-86, Jacob Jacobszoon van der Meer), while subsequent ones were published in Antwerp (1511, Hendrick Eckert van Homberch; before-1517, attributed to Claes de Grave; 1517, Claes de Grave; 1520, Hendrick Eckert van Homberch; c. 1530-40, Hendrick Peeterssen van Middelburch). All these editions have woodcuts on the title page but not one of these was designed for this specific work. All were fifteenth-century cuts re-used in a new setting. This article argues that this was a deliberate, rather than a convenient or careless, choice: re-editions of medieval narratives were furnished with older woodcuts as indicative of the genre. This is illustrated by the edition of 1517 in which an older woodcut is framed within a more modern, contemporary woodcut border. This shows that although the printer had access to modern designs, he opted to illustrate Seghelijn with an older (indeed old-fashioned) frontispiece.
\end{abstract}

Seghelijn van Jherusalem ist ein Versroman aus dem vierzehnten Jahrhundert, der in einer Handschrift und sechs Drucken überliefert wurde. Seit Ingrid van de Wijer 1893 ihre Dissertation dem Text widmete, hat das Interesse am Seghelijn zugenommen und ist der Text Gegenstand einiger Studien gewesen. Diese befassen sich ausschließlich mit dem Text, während die Holzschnitte, die in den Drucken vorkommen, bis heute wenig Aufmerksamkeit erregt haben. Thema des vorliegenden Beitrags sind die Holzschnitte, insbesondere die Titelillustrationen. Der erste Druck erschien in Delft (1483-86, Jacob Jacobszoon van der Meer), während spätere Ausgaben in Antwerpen publiziert wurden (1511, Hendrick Eckert van Homberch; vor 1517, Claes de Grave zugeschrieben; 1517 Claes de Grave; 1520, Hendrick Eckert van Homberch; ca. 1530-40, Hendrick Peeterssen van Middelburch). Alle Ausgaben enthalten Holzschnitte auf dem Titelblatt, aber keiner davon wurde speziell für eine Seghelijn-Ausgabe angefertigt. In allen Fällen handelt es sich um eine Wiederverwendung älterer Holzschnitten aus dem fünfzehnten Jahrhundert. In diesem Beitrag wird argumentiert, dass das nicht nur eine Frage der Unachtsamkeit oder der Bequemlichkeit war, sondern eine bewusste Entscheidung: Ausgaben mittelalterlicher narrativer Erzählungen wurden vorzugsweise mit älteren Holzschnitten versehen zur Charakterisierung der Gattung. Illustrativ in dieser Hinsicht ist die 1517-Ausgabe, bei der ein älterer Holzschnitt in einen modernen, zeitgenössischen Rahmen eingefasst wurde. Sie zeigt, dass der Herausgeber zwar über moderne Materialien verfügte, für den Seghelijn aber eine ältere (und somit altmodische) Abbildung wählte.

Jef Schaeps, Leiden University

¿ Open Access. (C) 2019 Jef Schaeps, published by De Gruyter. (cc) BY-NC-ND This work is licensed under a Creative Commons Attribution-NonCommercial-NoDerivatives 4.0 International License.

https://doi.org/10.1515/9783110563016-011 
Seghelijn van Iherusalem is a fourteenth-century chivalric verse romance, written by an otherwise unknown author named Loy Latewaert. ${ }^{1}$ The text has been transmitted in a single manuscript and dates from around 1412-1415. Its six printed editions were published between circa 1485 and $1540 .^{2}$ "Not a work of genius" is one of the milder, if still pejorative, judgments that have been used to characterize Seghelijn, yet in the first century after the invention of printing the text enjoyed considerable popularity. ${ }^{3}$ Seghelijn is one of the rare examples of Dutch chivalric verse romances that made it into print. ${ }^{4}$ Moreover, the printed editions of Seghelijn make up the highest number of editions in the corpus of Dutch printed romances (a number only equalled by the famous Charlemagne romance Karel ende Elegast, which was also printed six times before 1540). The text of Seghelijn, its genesis and its transmission have received a measure of scholarly attention in recent decades. The illustrations in the printed editions, however, have been studied less extensively. ${ }^{5}$ The aim of this article is to take a closer look at the woodcuts, especially those on the title-pages, to explore their origin and to see what their occurrence can tell us about the use and function of woodcuts in early printed editions of narrative literature in general.

\section{Historiography and Summary of the Text}

The first one to devote any attention to Seghelijn van Iherusalem was Henrik van Wyn, who described the text as "a concoction of foolish inventions". ${ }^{6}$

1 His name is mentioned in the last lines of the 1511 edition, published in Antwerp by Hendrick Eckert van Homberch: "Die dit dichte en[de] heft bescreuen | Was gheheeten loylate waert" (fol. 68). The name is now commonly spelled Loy Latewaert.

2 The manuscript is kept in the Staatsbibliothek in Berlin (Ms. Germ. fol. 922). The dating, mentioned in Ingrid van de Wijer, 'Segheliin van Iherusalem, tekstoverlevering van een Middelnederlands ridderdicht'. In: Quaerendo 14 (1984), p. 273-303 (p. 284), is based on the manuscript's watermarks. There will have been older manuscripts, now lost, that go back to the middle of the fourteenth century.

3 Van de Wijer, 'Segheliin van Iherusalem' (note 2), p. 273: "geen hoogvlieger.” [On the popularity of Seghelijn van Jherusalem and Karel ende Elegast both in manuscript and in print, see the article by Besamusca and Willaert in this volume, p. 71-72, p. 82 and p. 83.]

4 See on the exceptional status of Seghelijn as a narrative printed in verse: Rob J. Resoort, 'Het raadsel van de rijmdrukken'. In: Nederlandse Letterkunde 3 (1998), p. 327-344.

5 So far, only Van de Wijer, 'Segheliin van Iherusalem' (note 2), has paid attention to the illustrations.

6 Henrik van Wyn, Historische en letterkundige avondstonden. Amsterdam 1800, p. 315, note b: "een saamenweefzel van dwaaze verdichtzelen." 
W.J.A. Jonckbloet, in his authoritative Geschiedenis der Nederlandsche letterkunde (History of Dutch literature), spoke of "wild romantic tales combined with vulgar fantasies and miracles."7 Jacob Verdam, who published a transcription of the manuscript and compared this to the printed editions, ascribed the negative assessments to a rather careless transmission of the text from manuscript to printed version. ${ }^{8}$ To Verdam we also owe the dating of the text to around 1330-1350. Of all the authors who wrote about narrative literature in the Early Modern period, only Emile Van Heurck devotes a passage to Seghelijn, while Luc. Debaene includes the book in his major work on Dutch prose romance, listing it in a seperate section of popular books that do not meet the generic definition of 'prose romance' and are therefore left without commentary. ${ }^{9}$ Ingrid Van de Wijer published an extensive study of Seghelijn in 1983, focusing on the codicology and transmission of the text. ${ }^{10}$ Some of her findings were published in an article, aimed at an international audience. ${ }^{11}$ Finally, W.P. Gerritsen and A.G. van Melle included Seghelijn in their 1993 survey of medieval narrative literature, in an essay written by G.H.M. Claassens. ${ }^{12}$ In recent years Seghelijn has been the subject of a reappraisal, resulting in a number of articles, centering around at the linguistic, literary and cultural aspects of the text. ${ }^{13}$

7 W.J.A. Jonckbloet, Geschiedenis der Nederlandsche letterkunde. Vol. 1. Groningen 1868, p. 332: "[...] wilde romantiek huwt zich daarin dan ook aan de wansmakelijkste legende-wonderen." And even though Jonckbloet somewhat toned down this judgment in the later editions of his Geschiedenis (2nd edition: 1873-1874, 3rd edition: 1881-1886, 4th edition (posthumous): 1882-1892), his negative verdict persisted.

8 Jacob Verdam (ed.), Seghelijn van Jherusalem naar het Berlijnsche handschrift en den ouden druk. Leiden 1878, p. IV and XII.

9 Emile Van Heurck, Les livres populaires flamands. Antwerpen 1931, p. 28; Luc. Debaene, De Nederlandse volksboeken. Ontstaan en geschiedenis van de Nederlandse prozaromans, gedrukt tussen 1475 en 1540. Antwerpen 1951, p. 267.

10 Ingrid van de Wijer, Segheliin. Codicologische, bibliographische en tekstkritische studie en editie (diss. Leuven). 2 vols. Leuven 1983.

11 Van de Wijer, 'Segheliin van Iherusalem' (note 2).

12 G.H.M. Claassens, 'Seghelijn van Jheruzalem'. In: Van Aiol tot de Zwaanridder. Personages uit de middeleeuwse verhaalkunst en hun voortleven in literatuur, theater en beeldende kunst. Ed. by W.P. Gerritsen and A.G. van Melle. Nijmegen 1993, p. 299-300.

13 See for example: G.H.M. Claassens, 'Die kerstenwet stercken. Kruisvaartideologie en kritiek in de Seghelijn van Jhersualem'. In: TNTL 107 (1991), p. 235-273; G.H.M. Claassens, 'Dat en is sonder reden niet. Over de zeven vragen van Seghelijn van Jherusalem'. In: Spiegel der Letteren 40 (1998), p. 25-54; An Faems, 'Nu hoert, ghi heren, ende verstaet ende neemt exempel aen desen man. De functie van het vertellerscommentaar in Seghelijn van Jhersualem'. In: Millennium 15 (2001), p. 114-139; G.H.M. Claassens, 'Membra disiecta: excessief geweld in de ridderroman Seghelijn van Jherusalem'. In: Kabaal! Feest en strijd in de Nederlandse literatuur. Ed. by Elke Brems, An Faems and Eveline Vanfraussen. Leuven 2004, p. 25-55. More 
Seghelijn is an indigenous Middle Dutch text, consisting of a compilation of narrative elements known from many other texts. Born in Jerusalem to an Islamic family, son of King Pridus and Queen Braffeleur, it is foretold that Seghelijn will kill his father. His mother hides him from his father's persecution and Seghelijn is raised by a fisherman. While still a young man Seghelijn is engaged by his father as a courtier without being recognised. His luck doesn't last long, however, and soon he has to flee the court due to a conspiracy. This is the start of a rollercoaster of wondrous and exciting adventures: Seghelijn defeats giants and other adversaries, he sleeps with seven virgins on seven consecutive days and fathers seven sons. For this he is imprisoned for fifteen years and after his release he joins his seven sons, who were to become the Seven Wise Men of Rome, in an attempt to end the siege of their hometown Oliferne. Finally he marries Emperor Constantine's daughter Florette. This seems to initiate a more quiet phase in Seghelijn's life, but it does not last long. Empress Helen takes Seghelijn on a succesful journey to find the Holy Cross, but in the meantime his wife Florette is subjected to a heinous series of atrocities. After Constantine and Helen's deaths, Seghelijn becomes the new Emperor. Due to further conspiracies, Seghelijn accidentally kills his parents when they visit Rome on a pilgrimage, thus fulfilling the prophecy from his childhood. After having been suspected of adultery by Seghelijn, Florette dies of grief. Seghelijn withdraws into the wilderness for some years, only to be elected pope later on. ${ }^{14}$

The son who is separated from his parents and destined to kill them, the wandering through many regions and countries, the service of kings and emperors, the succession of some of the most unlikely adventures and the final apotheosis - these are elements borrowed from other well-known stories, which have been gathered here into a kaleidoscopic trip through medieval imagery.

\section{Printed Editions and their Woodcuts}

The first printed edition of Seghelijn van Jerusalem was published in Delft by Jacob Jacobszoon van der Meer between 1483 and 1486 (ISTC is00366400;

references can be found in the online Bibliografie van de Nederlandse taal- en literatuurwetenschap (BNTL, www.bntl.nl).

14 For a more comprehensive summary see Van de Wijer, 'Segheliin van Iherusalem' (note 2) and Claassens, 'Seghelijn van Jherusalem' (note 12). 
GW 12790). ${ }^{15}$ Seghelijn was not the first narrative text that van der Meer published. In May 1479, during his companionship with Mauricius Yemantszoon van Middelborch, he had produced an edition of the history of Alexander the Great (ISTC ia00401000; GW 892) and in January 1483 he had printed Hystorie van die seven wise mannen van Romen (ISTC is00450150; GW 12877). Both texts followed earlier editions by Gerard Leeu in Gouda. Like all books printed by Jacob van der Meer and Mauricius Yemantszoon - they had started their career in January 1477 with the famous Delft Bible - Dat leven ende dat regiment des coninc Alexanders did not have a separate title-page, nor were there any woodcuts included in the book. The Hystorie van die seven wisen mannen van Romen was also devoid of a title-page, but in this case the publisher used a series a woodcuts, starting with an image opposite the first page. ${ }^{16}$ Other narrative texts followed. The prose version of Reynaert de Vos is dated 4 June 1485 (ISTC ir00136000; GW 12726) and is more or less contemporary with the undated Seghelijn. Later, in 1487-1488, van der Meer produced an edition of Karel ende Elegast (ISTC ic00204700; GW 12601) and a second edition of Die historie van die seven wijse mannen van Roemen, undated but produced between April 1487 and August 1491 (ISTC is00450300; GW 12879).

When van der Meer printed Seghelijn, he was unable to rely on any previous editions. As a novelty he inserted a title-page before the start of the text. ${ }^{17}$ Around ten years after the introduction of printing in the Low Countries, titlepages were still a rarity. Books started either with the text, a preceding table, or a blank page. The title-page of Seghelijn has the title at the top of the page and two small woodcuts of a knight and a nobleman on horseback (Fig. 1). The title reads: Die historie va[n] seghelijn van iherusalem. The two woodcuts actually represent chess pieces, which van der Meer had already at his disposal in his workshop. They were cut, together with 14 other woodcuts, for Jacobus de Cessolis' book on chess, in a Dutch translation entitled Scaecspel that had been

15 Ina Kok, Woodcuts in Incunabula Printed in the Low Countries. 4 vols. Houten 2013 (hereafter cited as Kok) dates the book between 14 February 1483 and 25 March 1486. A unique copy is kept in the University Library in Ghent (Res. 1405).

16 The book contains 16 full-page woodcuts, including many repeats. See Kok (note 15), nr. 32.

17 This was already noted by Ursula Rautenberg, 'Die Entstehung und Entwicklung des Buchtitelblatts in der Inkunabelzeit in Deutschland, den Niederlanden und Venedig Quantitative und qualitative Studien'. In: Archiv für Geschichte des Buchwesens 62 (2008), p. 1-105: "Die Ausgabe des Versromans Seghelijn van Jerusalem [. . . zeigt möglicherweise eine der ersten illustrierten Titelseiten.” (p. 69). Based on this fact Rautenberg is inclined to date Seghelijn to the end of the time period, set by Kok (see note 15), that is 1486. [For title-pages, see also the contribution by Syrovy in the present volume, p. 351-374.] 
published on 14 February 1483 (ISTC ic00412000; GW 6537). ${ }^{18}$ Nevertheless, the woodcuts are appropriate here. Seghelijn abounds in knights and noblemen and the way they are printed, opposing each other with raised lances, corresponds to the many combats Seghelijn would be involved in. Title pages with more than one woodcut are otherwise unknown during this period. When a book does have a title-page with an illustration, it is always just one and, in this period, these often represent devotional images or a magister cum discipulis scene. By printing the woodcuts close to the title, leaving a large part of the page blank, one of the later owners of the only known copy in Ghent was incited to add a few woodcuts of their own. A scene of the circumcision and two separate architectural side pieces have been pasted onto the title-page. ${ }^{19}$ They stem from the printing shop of Gerard Leeu and date from shortly after the printing of Seghelijn. ${ }^{20}$ It is likely that the same owner added three more biblical woodcuts to the reverse side of the title-page. ${ }^{21}$ There are no other woodcuts included in the book, neither printed nor added by a later hand. The edition by van der Meer is the only one to have been published in the Northern Netherlands; all consecutive editions were published in Antwerp.

Some 25 years later a new edition of Seghelijn was printed and published by Hendrick Eckert van Homberch. ${ }^{22}$ Like van der Meer, Eckert resided originally in Delft, but in 1500 he had relocated to Antwerp. He was in the possession of many woodcuts he had purchased from earlier printers such as Jacob Bellaert from Haarlem and Gerard Leeu who had been active in Gouda and Antwerp. Eckert's edition of Seghelijn is dated 16 March 1511 (Fig. 2). The titlepage is of a type common in the second decade of the sixteenth century: the first words of the title (preceded by an ornament) are cut from a woodblock

18 The date of Scaecspel determined the terminus post quem for Seghelijn, see Kok (see note 15). 19 Van de Wijer, tekstkritisch studie en editie (note 10) apparently felt unsure about whether the woodcuts were printed or added manually through pasting. She writes: "werden waarschijnlijk later opgeplakt" [tr. probably pasted in at a later time] (p. 101). In her article in Quaerendo (note 2, p. 289) she just mentions the woodcuts, without saying anything about their status. Rautenberg (see note 17) was misled by a photograph or digital image: she describes the circumcision scene as part of the printed book (p. 69).

20 William Martin Conway, The Woodcutters of the Netherlands in the Fifteenth Century. Cambridge 1884. For the circumcision see Conway, 9.2.11 and Kok (see note 15), 74.11. For the sidepieces see Conway 10.7 (3) and 12.11.7; and Kok (see note 15), 85.96 and 85.108.

21 Conway (see note 20), 10.6.116, 10.6.129 and 12.3.10; and Kok (see note 15), 85.16, 85.48 and 85.66 .

22 een seer / schone historie van seghelijn van iherusalem (NK 1322). There is a unique copy in the Koninklijke Bibliotheek in The Hague (KW 227 A 4). 


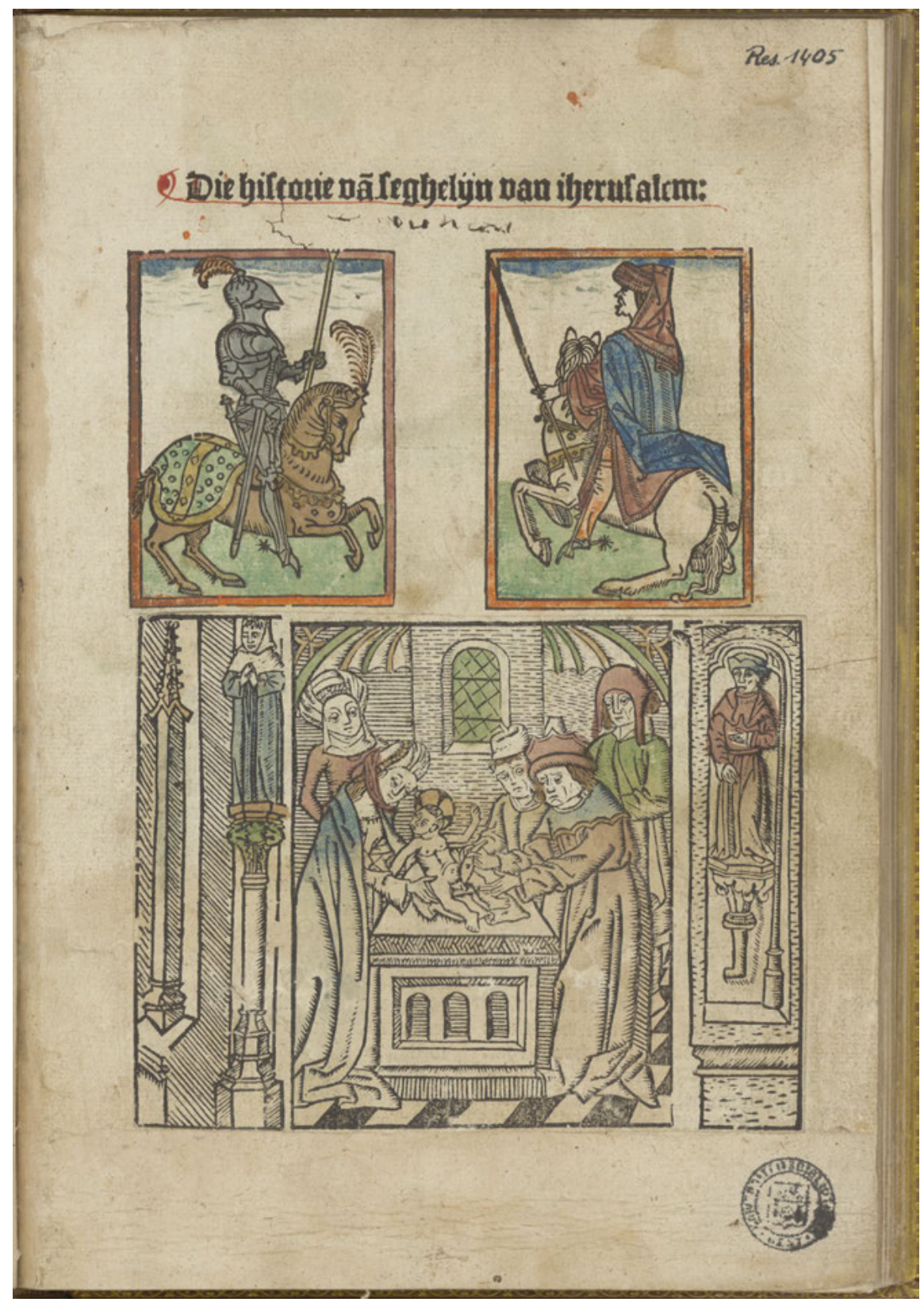

Fig. 1: Title-page of Seghelijn van Iherusalem, Delft, Jacob Jacobszoon van der Meer, 1483-1486 (Ghent, University Library). 
and printed in red. The remaining part of the title is set underneath in type and printed in black. Finally a narrative woodcut is printed below the text, in this case with an additional ornamental frieze. The title reads: een seer schone historie van seghelijn van iherusalem (a very beautiful history of Seghelijn of Jerusalem). The woodcut shows a combat scene in front of city walls. The page's design (woodcut title, remainder of the title in type and woodcut image) was common within title-pages from this period and, moreover, one that is not confined to narrative literature alone but can be found in other genres as well. ${ }^{23}$ Although the woodcut may be appropriate to the story of the romance, in fact it dates from 1483-1485, when it was used by Jacob Bellaert in Historie van den vromen ridder Jason (ISTC il00111000; GW M17467) and reused in Vergaderinge der historien van Troyen (ISTC il00116000; GW M17453). ${ }^{24}$ In these books the woodcut represents King Apollo fighting King Zetephius. Since scenes from Greek and Roman history were usually represented by medieval knights, the woodcut was apparently considered fit to illustrate Seghelijn. Bellaert's woodcut passed into the hands of Gerard Leeu and thence to Hendrick Eckert.

The third edition of Seghelijn is, unfortunately, not dated, nor does it have the name of a publisher. It is generally attributed to the Antwerp printer and publisher Claes de Grave (Fig. 3). ${ }^{25}$ The title-woodcut (Die historie va[n] seghe/ lijn van iherusalem) is reused in the next edition from 1517, which has De Grave's name in the colophon, making it likely that he was also the publisher of the earlier edition. This third edition of the text of Seghelijn is usually referred to as the pre-1517 edition. Besides the title, the page displays a large woodcut with narrative scenes and it takes the viewer some time to decipher the illustration which should actually be read from foreground to background. In the front, we find a walled city that is guarded by a giant, standing on the bridge leading to the city's gate. In the next scene the giant is having a sword fight with a knight. Subsequently, the giant is defeated by the knight and in the hindmost scene the giant has disappeared, while the knight is resting next to a river, holding a larger hand in his own gloved hand. Even further in the background an approaching army on horseback is visible. This is an illustration of

23 Conway (see note 20), 11.6.13 and Kok (see note 15), 160.13. The woodcut is repeated on k2, being the sole woodcut in the book.

24 Jason is to be dated between 10 December 1483 and 5 May 1485, Troyen is dated 5 May 1485. [Cf. the contribution by Besamusca and Willaert in the present volume, p. 73.]

25 The unique copy, kept at Leiden University Libraries (1498 C 3), lacks the last pages with a supposed colophon. NK 1323. 


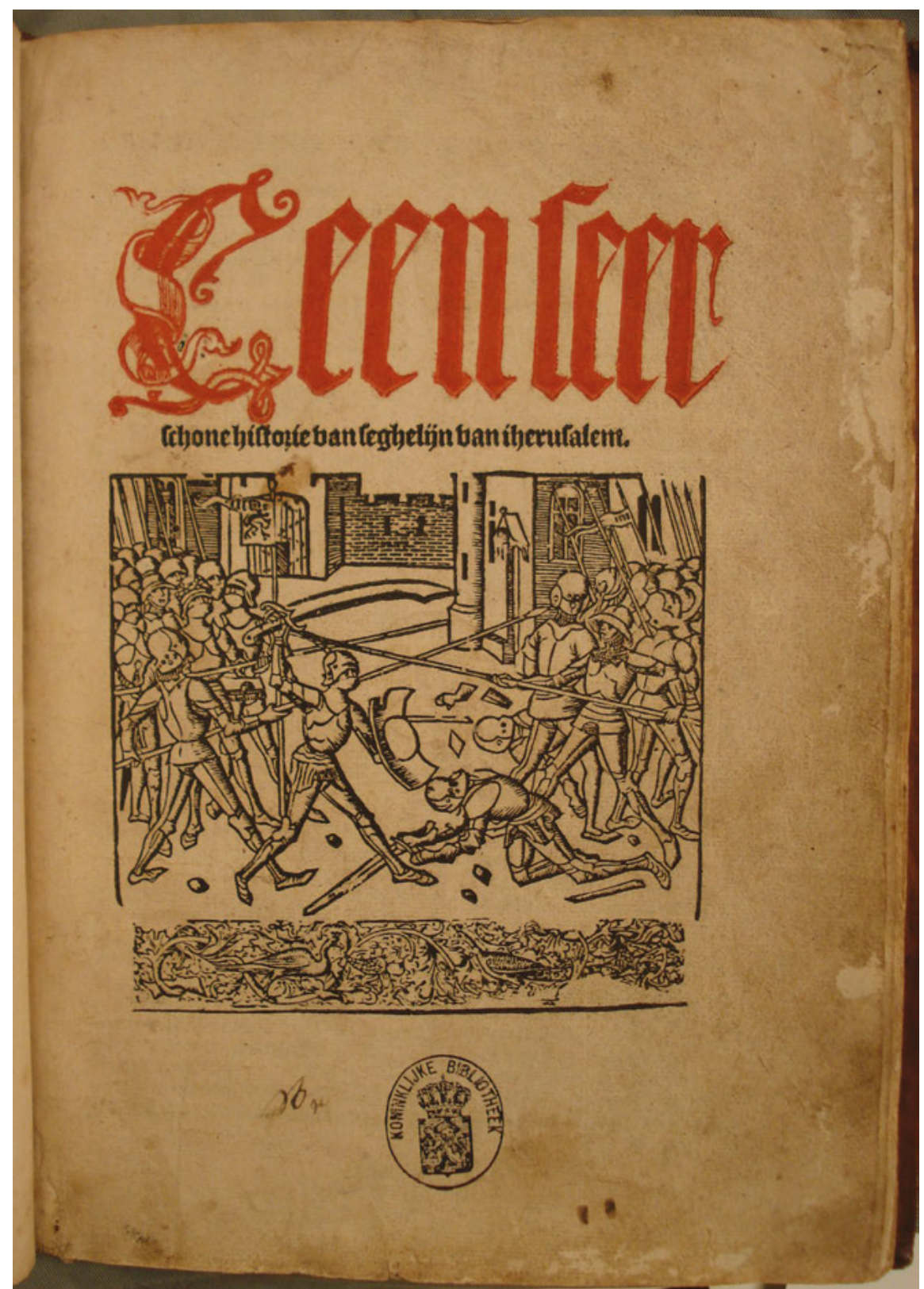

Fig. 2: Title-page of Seghelijn van Iherusalem, Antwerp, Hendrick Eckert van Homberch, 1511 (The Hague, KB). 
a well-known Antwerp legend, the defeat of the giant Druon Antigoon, who ruled the city as a tyrant, by the young hero Silvius Brabo. Brabo cut off the giant's hand and threw it into the river Scheldt. Not only did this story provide the city of Antwerp with a legendary and heroic past, it also gave meaning to the city's name. To throw a hand, or as they say in Dutch, 'een hand werpen' is taken as the origin of Antwerpen.

The woodcut was initially produced for the Cronike van Brabant, published by Roelant van den Dorpe in Antwerp in February 1497 (ISTC ic00475000; GW 6667). ${ }^{26}$ These Chronicles contain a large number of woodcuts, the majority much smaller than this page-filling scene. The print shop of Roelant van den Dorpe, which only published ten books, closed in 1501, one year after Roelant passed away. The woodcuts of the Cronike were at some point acquired by Jan van Doesborch, who used them in new editions of the same Chronicles, published in 1512, 1518 and 1530. The 1512 edition as well as the 1518 edition contain the Druon Antigoon - Brabo woodcut, in 1512 in a more pristine condition than in the pre-1517 Seghelijn. Pre-1517 thus implies post-1512. Both Van Doesborch editions of the Chronicles from the second decade also contain two woodcuts that have been re-used in the pre-1517 Seghelijn: two small battle scenes printed next to each other and another larger battle scene. ${ }^{27}$ They also originate from Van den Dorpe's Cronike, where the two smaller ones were still joined. In 1512, however, they were separated, although printed as if joined.

\section{The 1517 Edition by De Grave}

Claes de Grave was a publisher active in Antwerp from the second to the fourth decade of the sixteenth century. He had started his firm in 1511 and, the following year, managed to obtain a privilege to be able to print (for a period of six years) all books not formerly printed in Brabant. Like the majority of his competitors, De Grave's firm was located near the Cam[m]erpoort, the centre of the book publisher's quarter, in a building named after the nearby cathedral Onser liever vrouwen (Our Lady), an address he would keep until the end of his

26 Die alder excellentste cronyke van Brabant. For the Brabo woodcut: Conway (see note 20), 37.1.25 and Kok (see note 15), 306.25.

27 Conway (see note 20), 37.1.27 and 30; and Kok (see note 15), 306.32 and 306.35. 


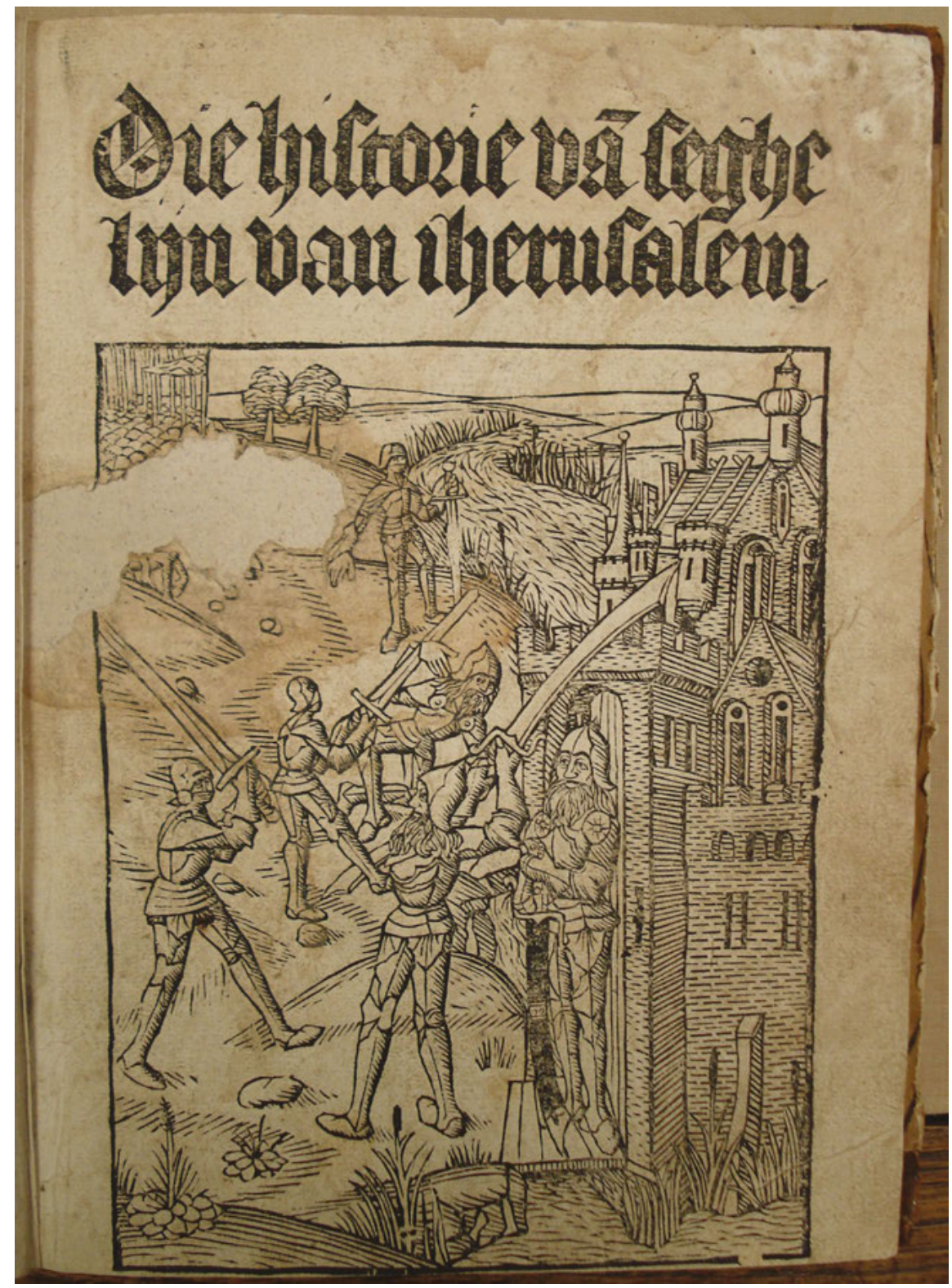

Fig. 3: Title-page of Seghelijn van Iherusalem, Antwerp, Claes de Grave (attr.), before 1517 (Leiden, UB). 
career. De Grave's firm produced on average three books a year, which makes it likely that he had revenues from other sources as well. ${ }^{28}$ His production is rather diverse, including devotional works (some Lutheran), Bibles, government publications, prognostications and scientific books (botany, medicine, history, law). At the beginning of his career he cooperated with Thomas van der Noot from Brussels a number of times who, in those instances, probably acted as the printer. However, towards the end of his working life, in the 1530s, Willem Vorsterman was his partner. Although the majority of his books were printed in the vernacular, Seghelijn is his only verse romance.

De Grave's pre-1517 edition had a title-page with a single woodcut, apart from the book's title, which was cut from a woodblock as well. Different from Eckert van Homberch, whose two editions (1511 and its 1520 reprint, which is discussed below) looked almost identical, De Grave made a radical change for his 1517 edition (Fig. 4). ${ }^{29}$ The title was printed from the same woodcut but had now become part of a page covered by a multitude of smaller woodcuts. The central woodcut shows a well-known biblical scene, the Fall of Jericho, originating from the workshop of Gerard Leeu. ${ }^{30}$ It was part of a large series of biblical woodcuts that Leeu employed in a number of books, although the presumed Bible or other book for which they were intended has not survived. ${ }^{31}$ Claes de Grave must have acquired the woodcut, and others from the same series, before January 1516, when he used some of them in his illustrated Bibel int corte ghetranslateert. ${ }^{32}$ The three border pieces, at the top, bottom and left margins, were copied from a Basel border. Finally De Grave added seven small decorative pieces to fill out the remaining voids. The effect is visually intimidating, the result of an unrestrained horror vacui that leaves the spectator baffled. The stylistic incongruity resulting from the combination of all these different parts is perhaps the most conspicuous characteristic of this

28 The USTC lists 87 publications with Claes de Grave's name, published between 1511 and 1543. Most years he produced two to five titles but some years remained without any output at all, while the years 1520 and 1539 were exceptional thanks to a large number of government publications.

29 Die historie va[n] seghe/lyn van iherusalem (NK 1324). A unique copy is kept in the Koninklijke Bibliotheek in The Hague (KW 227 A 14).

30 Conway (see note 20), 10.6.68; not in Kok but belonging to her series 85 .

31 Conway (see note 20), p. 56 suggests ,[... [ that the series would be found solely in a book for which it was specially intended, [...]”. The Old Testament scenes were used by Leeu in several Ludolphus de Saxonia editions, the New Testament ones only turned up with later printers in the sixteenth century and were apparently never employed by Leeu.

32 NK 366. 


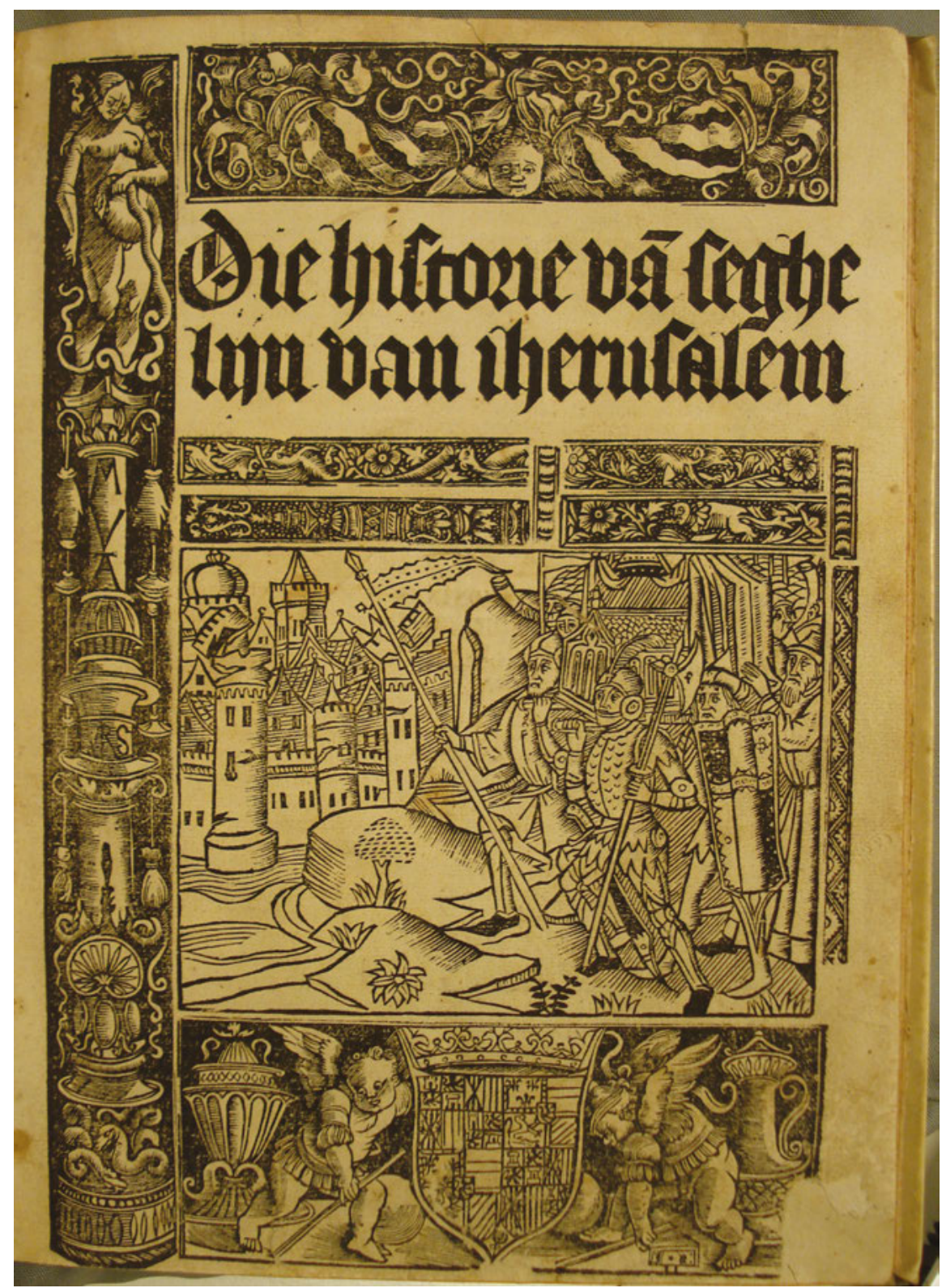

Fig. 4: Title-page of Seghelijn van Iherusalem, Antwerp, Claes de Grave, 1517 (The Hague, KB). 
title-page. Chronologically they range from the 1480s (for the biblical scene) to 1517 (for the border pieces).

The border that De Grave had copied for this edition of Seghelijn had originally been cut for the 1515 edition of Erasmus' Adagia, published by Johann Froben. This was a famous edition. In 1513 Froben had illegally, in other words without the author's consent, published an edition of the Adagia, copied from the earlier version, printed in Venice by Aldus Manutius. Although Erasmus was not happy with this pirated edition, he did admire the skill displayed by Froben and decided to have the 1515 edition published by him. ${ }^{33}$ It had a woodcut on the title-page displaying 'portraits' of Greek and Roman philosophers and writers, but on the second page, framing the preface to the reader, a four-part border was used (Fig. 5), the one that was copied two years later by Claes de Grave. The left part shows Eve, holding the snake, standing on a decorative column. The part on the right, somewhat wider, shows two columns, the front one similar to the one in the left piece, the one in the back of a more plain nature, with a putto standing on top. The upper part shows garlands of peapods with a cherub's head in the centre, while the bottom part has two winged angels, standing next to vessels and flanking an empty shield. The border was designed by the artist Urs Graf, who signed it twice: the bottom part has his usual monogram, VG, while the letters VRS are inscribed on the column in the left piece. The letters MVA on the same column should probably be read as EVA, who tops that column. ${ }^{34}$ The border was one of two stylistically related four-part borders that Graf designed simultaneously and that were used the next year, in various combinations, in an even more famous book, the Novum Instrumentum, Erasmus' edition of the New Testament in Greek (1516). Parts of these two borders can also be found in later editions of the Novum Instrumentum, those of 1519 and 1522 (Fig. 6).

Urs Graf was, along with Hans Holbein, the most prominent artist in Switzerland and the author of a great number of woodcuts for publishers in Basel. His border for Erasmus' Adagia was inspired by a slightly older one by Albrecht Dürer that had been used in a number of books, edited by his close

33 Margaret Mann Phillips, The Adages of Erasmus. A Study with Translations. Cambridge 1964, p. 119-121. The evolution of Erasmus' cooperation with Johann Froben can be traced through Erasmus' letters, which lead from an angry humanist in 1513 to one involved in a whole range of publishing projects with Froben in 1515.

34 This is the suggestion of Hieronymus Frank, Oberrheinische Buchillustrationen, 2. Basler Buchillustration, 1500-1545. Basel 1984, p. 144-145, No. 175. 


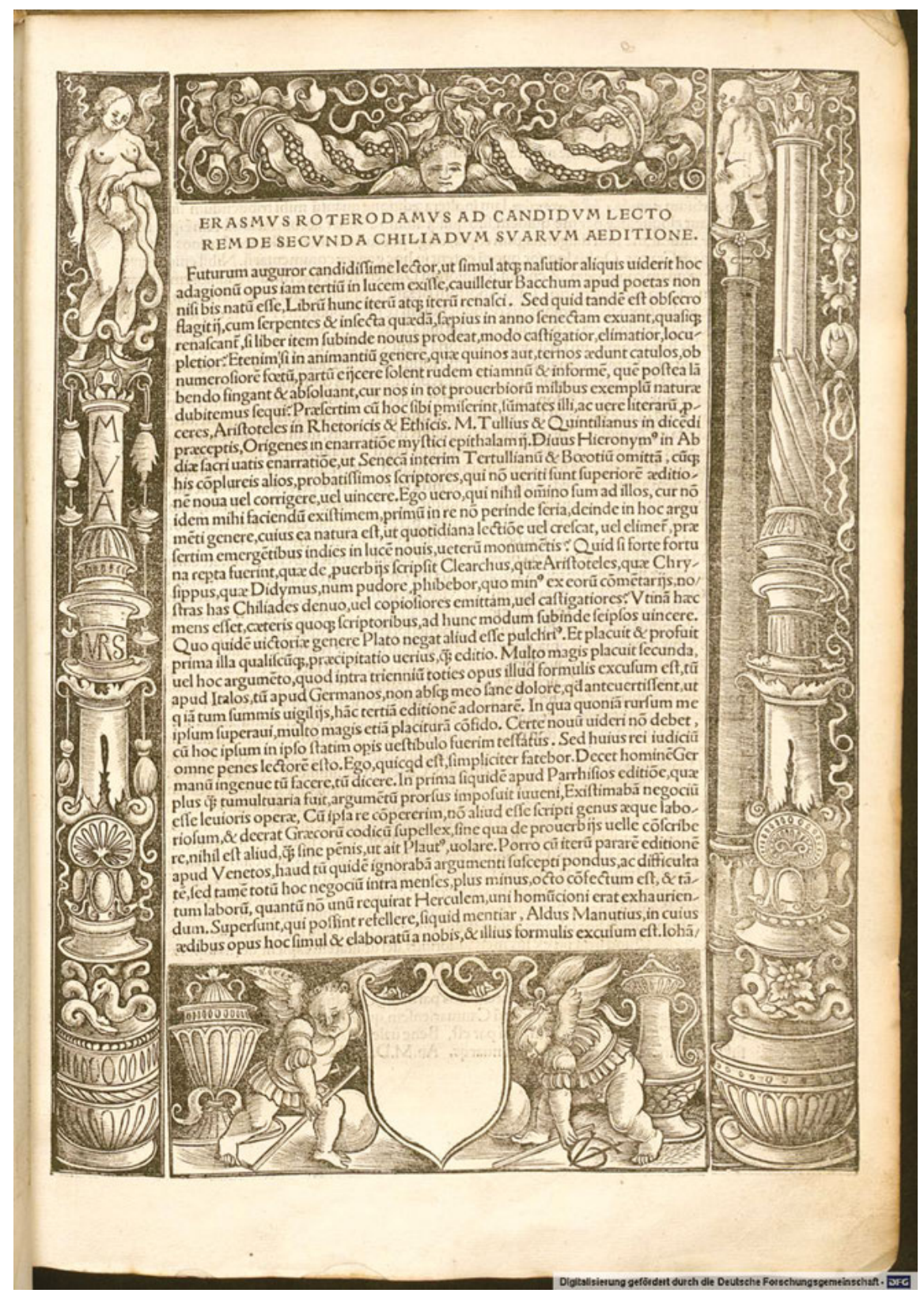

Fig. 5: Erasmus, Adagia, Basel, Johann Froben, 1515 (Munich, SB). 


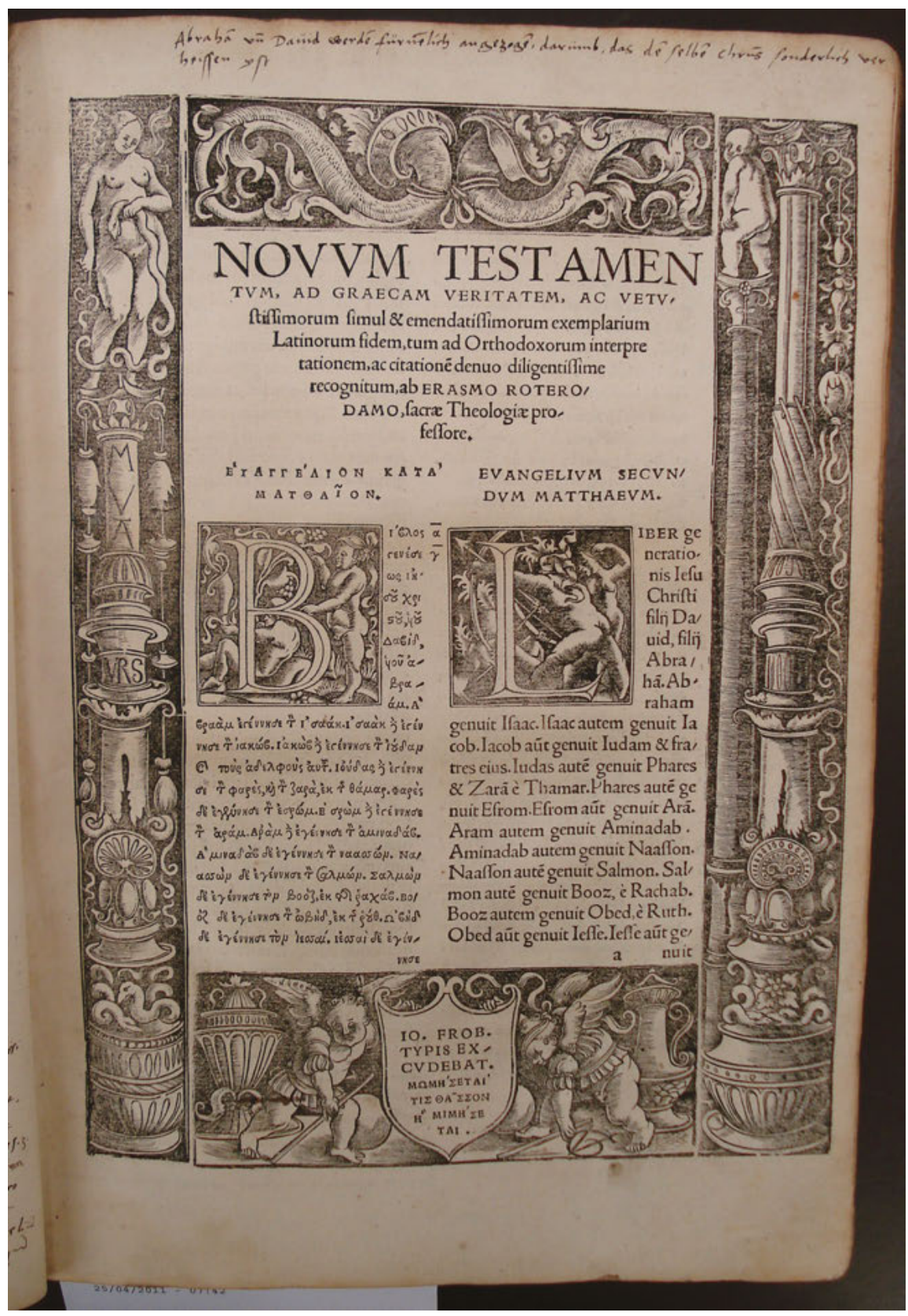

Fig. 6: Erasmus, Novum Testamentum, Basel, Johann Froben, 1522 (Munich, SB). 
friend Willibald Pirckheimer. These editions of Greek and Roman authors were published in Nuremburg by Friedrich Peypus. The first book to include Dürer's border was a 1513 edition of Plutarchus' De his qui tarde, where it framed the first text page (Fig. 7). ${ }^{35}$ In later books the border was used on the title-page. These included editions of (again) Plutarchus, Nilus and Lucianus Samosatensis. ${ }^{36}$ Unlike Graf's design, which consisted of four separate parts, Dürer's border was a true border woodcut forming a single image, creating continuity in the design, with the text field conceived as an illusionistic tablet hanging in front of the columns, stairs, fabled creatures and angels. Although the execution of the woodcut is generally attributed to Dürer's workshop, the design must have been his: Pirckheimer was Dürer's closest friend in Nuremberg and it is unlikely that the artist delegated his friend's request for a woodcut border to his workshop without being involved in the design.

Graf's four-part woodcut border is not a slavish copy of Dürer's but the dependency is obvious. The two columns on the right are almost identical, although Graf replaced Dürer's satyr with a putto. The garlands at the top are very similar but whereas Dürer put some fabulous creature at the centre where the garlands meet, Graf chose a cherub's head. For the bottom part Dürer depicted four angels, two holding Peypus' coat of arms and two blowing a trumpet. They were more or less copied by Graf, not in the bottom part used in the 1515 Adagia, but in the second border used in the Novum Instrumentum of 1516. For the left part of the woodcut, Dürer created a complicated architectural setting with steps, a baluster, a heron on a column and dangling grapes. Graf replaced these with a single column of elaborate design, not unlike the one on the right side, with the figure of Eve on top.

By copying the woodcut border by Urs Graf, inspired by Albrecht Dürer and using it in his edition of Seghelijn, Claes de Grave introduced a specimen of Renaissance book design into the Low Countries. Designs of such modernity were still a rarity and although notions such as 'old-fashioned' or 'modern' or stylistic concepts such as 'gothic' and 'renaissance' may be anachronistic to use here, De Grave must have been aware that he was copying something not seen before in his homeland. The woodcutter must also have taken some pride

35 VD16 P 3634. This, and the books mentioned in the next note, can be accessed through the VD16 website.

36 Plutarchus, De vitanda usura, 1515 (VD16 P3783 and P3784), Lucianus Samosatensis, De ratione conscribendae historiae, 1515 (VD16 L3033 and L3034), Nilus, Sententiae morales, 1516 (VD16 N1759 and 1760) and Lucianus Samosatensis, Piscator seu reviviscentes, 1517 (VD L3033). 


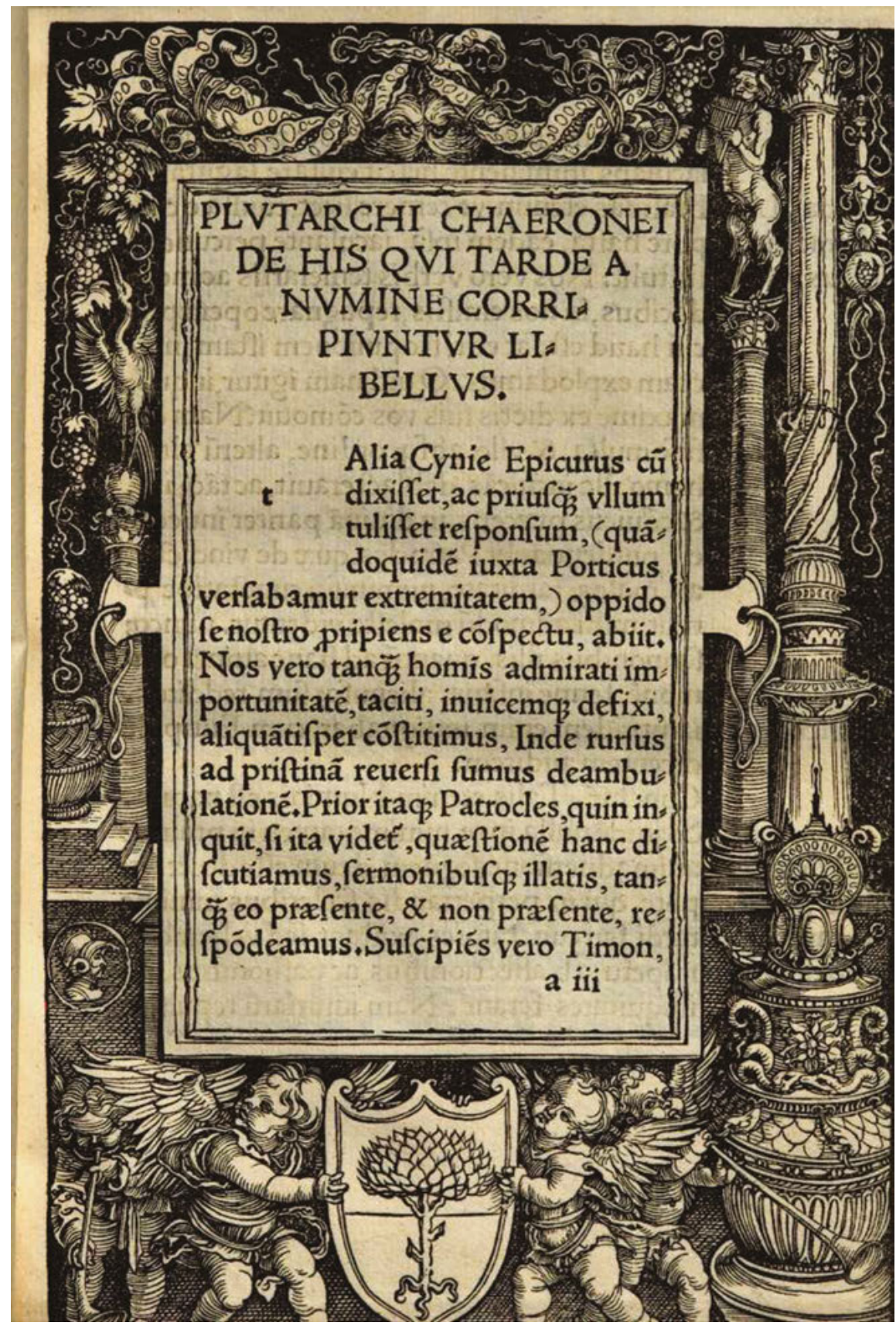

Fig. 7: Plutarchus (W. Pirckheimer ed.), De his qui tarde, Nuremberg, Friedrich Peypus, 1513 (Munich, SB). 


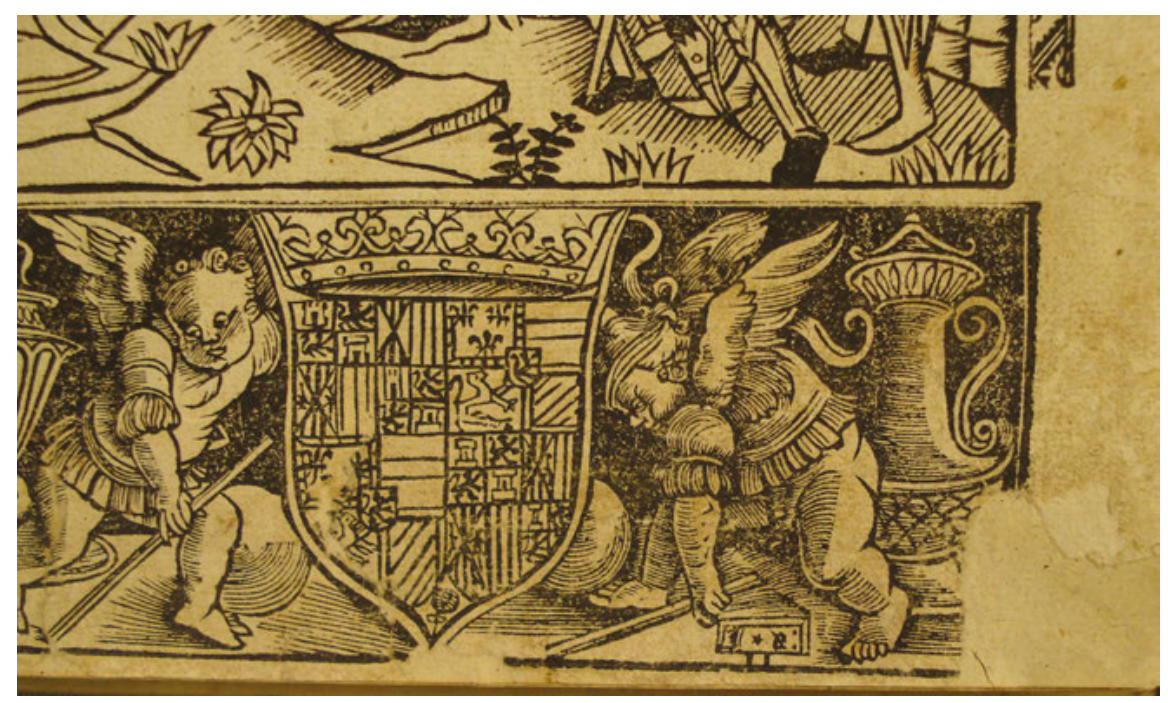

Fig. 8: Detail of Fig. 4.

in his work. He signed the design with his monogram inscribed on the lower right side on a tablet (Fig. 8). Indecipherable as it is ( ${ }^{*} \mathrm{~S}$ ?), it is one of the oldest signatures to be found in book decoration in the Low Countries. ${ }^{37}$ That De Grave did not fully embrace or even appreciate the innovative nature of the design can be deduced from his only partial application (he left out the right part), the combination with a much older woodcut and the repeated use in books, none of which contains a contemporary text. After Seghelijn, parts of the border - never all four together - were used by De Grave in Den grooten Cathoon (1519 and 1535), Somme ruyrael (1520 and 1529) and Ludolphus de Saxonia's Vita Christi (1521, in Dutch). ${ }^{38}$ In this last book, De Grave used the border not on the title-page, but to frame the Lentullus-portrait of Christ, exchanging the left and right parts and thus ignoring Urs Graf's discerning characteristic of making the right side - corresponding to the outer margin of the page - wider. The combination of Urs Graf's design with much older woodcuts

$37 \mathrm{I}$ * $\mathrm{B}$ is another option. I haven’t been able to find another example in early book decoration in the Low Countries. The monogram is not registered in G.K. Nagler, Die Monogrammisten. 5 vols. Munich 1858-1879.

38 NK 542, 543, 481, 482 and 1411. 
such as we saw in Seghelijn was repeated in the other books. Thus, although Claes de Grave introduced a state-of-the-art woodcut border in the Low Countries, the way he applied it was outdated.

\section{Seghelijn Editions after 1517}

In 1520 Hendrick Eckert van Homberch republished his Seghelijn (Fig. 9). ${ }^{39}$ This edition is almost identical to the one he had published in 1511, the two titlepages being virtually indistinguishable. There is a slight change in the spelling of the title: schone historie van seghelijn van iherusalem became schoone hystorie van seghelijn van Iherusalem. But the composition of the title-page remained the same, although the decorative border piece below the narrative woodcut was replaced by a different one. While the 1511 edition had no other woodcuts but the titular one, repeated twice in the text, the 1520 edition used a different woodcut for the book's interior, which was repeated four times. ${ }^{40}$ And, like the titular woodcut used earlier in Bellaert's Jason, the one inside the book, showing a military tent camp, was used by Bellaert as well, but in a different book, the 1485 Vergaderinge der historien van Troyen (ISTC il00116000; GW M17453), where it represented the siege of Troy by the Greeks. ${ }^{41}$

The last edition of Seghelijn to be published in the Low Countries (or anywhere, for that matter) was again printed in Antwerp, by Hendrick Peetersen van Middelburch around $1540 . .^{42}$ Like Claes de Grave before him, Peetersen used a woodcut from Roelant van den Dorpe's Cronike van Brabant on the titlepage (Fig. 10). ${ }^{43}$ It represents a battle scene that originally was meant to portray the Battle of Cordoba (1236) but could equally be applied to one of the many battles Seghelijn was involved in. The space underneath the battle woodcut was filled by Peetersen with stock images from his workshop. The lower border piece includes a coat-of-arms with the initials IL. These refer to Jacob van Liesveldt, making it probable that van Liesveldt was the publisher and Peetersen the printer. Peetersen (or van Liesveldt) could have borrowed the

39 NK 3364. The Österreichische Nationalbibliothek in Vienna holds the only known copy (66.E.39). [On Hendrick Eckert van Homberch see also the contribution by De Bruijn in this volume, p. 113-115.]

40 The woodcut can be found on fols. E1, F5, G1 and H2.

41 The woodcut: Conway (see note 20), 11.7.10; and Kok (see note 15), 162.10.

42 NK 3365. A unique copy is kept in the Bibliothèque nationale de France in Paris (Res-YI-27).

43 Conway (see note 20), 37.1.42; and Kok (see note 15), 306.42. 


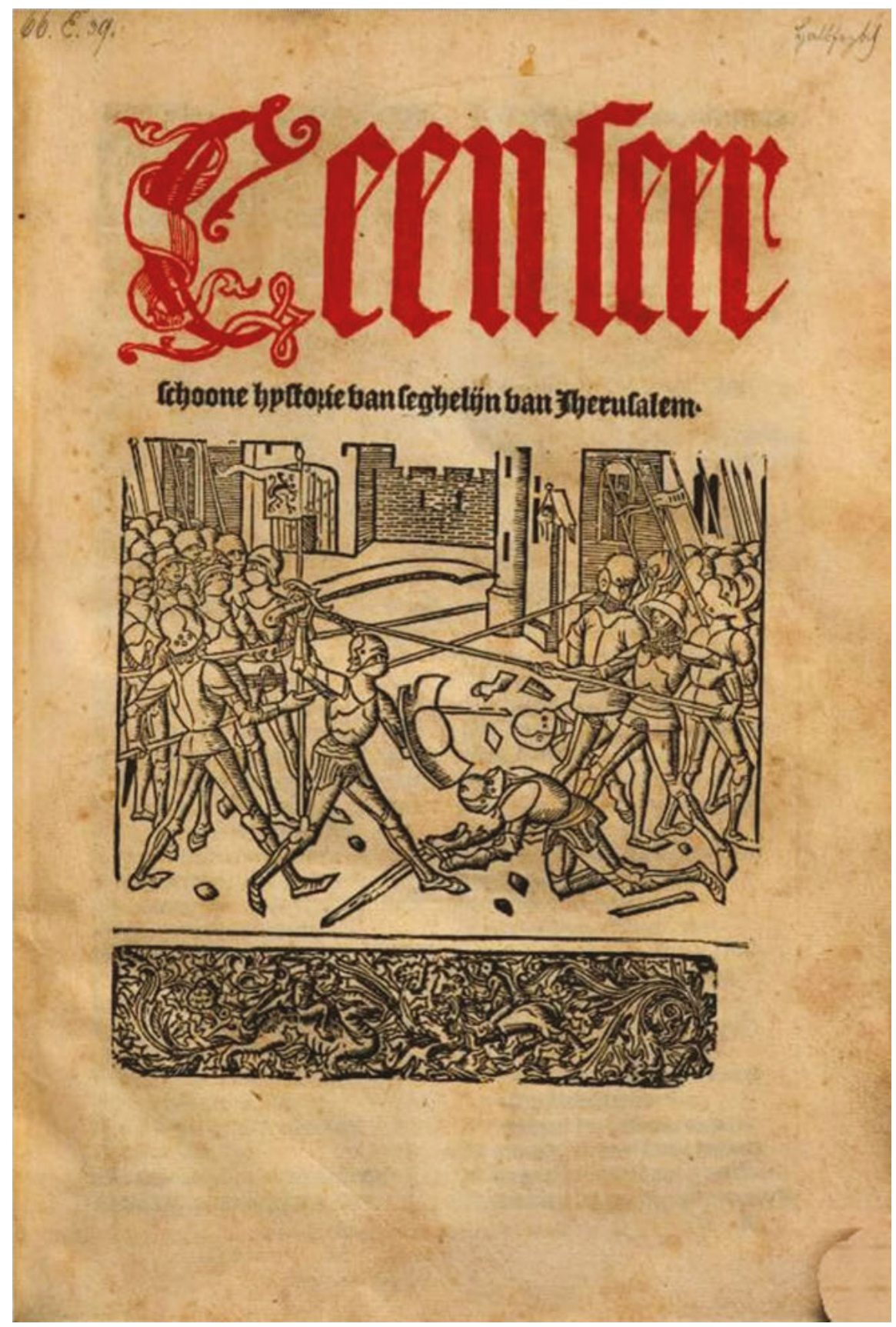

Fig. 9: Title-page of Seghelijn van Iherusalem, Antwerp, Hendrick Eckert van Homberch, 1520 (Vienna, ÖNB). 

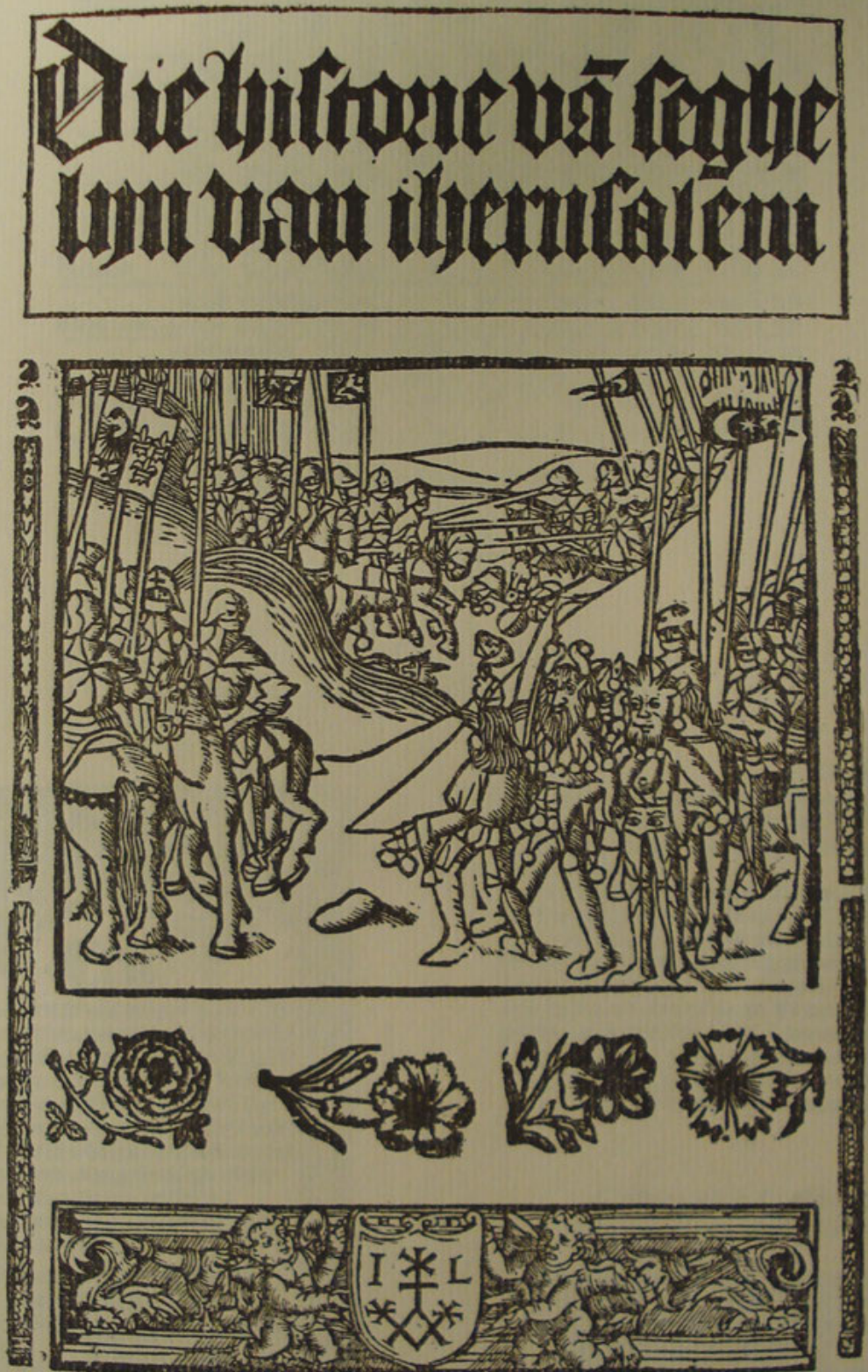

Fig. 10: Title-page to Seghelijn van Iherusalem, Antwerp, Hendrick Peetersen van Middelburch for Jacob van Liesveldt, 1540 or earlier (Paris, BN). 
battle woodcut from Jan van Doesborch. Some copies of Van Doesborch's Chronicles, using van den Dorpe's woodcuts, were actually printed for Peetersen. ${ }^{44}$ This could be an argument to date Peetersen's Seghelijn closer to 1530, when van Doesborch and Peetersen were collaborating. ${ }^{45}$

\section{Use and Re-Use of Woodcuts in Narrative Prose}

Without exception, all the woodcuts that have been used in the six editions of Seghelijn are examples of the re-use of existing woodcuts. Not one woodcut was produced with the purpose of illustrating the Seghelijn text itself. The 1483-1486 edition by Jacob Jacobszoon van der Meer was illustrated by slightly older woodcuts from Van der Meer's own stock (Scaecspel, 1482-1484). The 1511 and 1520 editions by Hendrick Eckert van Homberch employed the same woodcut on their title-pages, an image originating from Jacob Bellaert, to be dated between 1483 and 1485 (Jason). The pre-1517 edition by Claes de Grave used a woodcut from Roelant van den Dorpe's Chronicles (1497), while the 1517 edition from the same publisher once more had a woodcut from Gerard Leeu on the title-page, one of a series of biblical prints, dated on or before 1487. This woodcut was surrounded by border pieces that were newly cut, although probably not specifically for this Seghelijn edition. These border pieces were copied after a Basel border designed by Urs Graf. The book contains a few woodcuts from Van den Dorpe's Chronicles to illustrate the text. The 1520 edition by Hendrick Eckert used, apart from the already mentioned title-page cut, woodcuts from a different book published by Jacob Bellaert, dated 1485 (Vergaderinge der historien van Troyen). The final edition from around 1540 or somewhat earlier, was published by Jacob van Liesveldt and again uses a woodcut from van den Dorpe's Chronicles on the title-page, one not used before in a Seghelijn edition.

So all the title woodcuts, with the exception of the copies after Urs Graf in the 1517 edition, date from before 1500. They were cut for different texts that served different needs and were intended for different audiences. Jacob Bellaert's

44 Peter J.A. Franssen, Tussen tekst en publiek. Jan van Doesborch, drukker-uitgever en literator te Antwerpen en Utrecht in de eerste helft van de zestiende eeuw. Amsterdam 1990, p. 85, No. 62. Franssen mentions that a number of the copies of Van Brabant die excellente cronike (1530) were printed for either Michiel Hillen van Hoochstraten or Hendrick Peetersen.

45 There is perhaps one other edition of Seghelijn, the title identical to the Van Liesveldt / Peetersen edition, dated 1564. It is mentioned by the USTC and located in the Bodleian Library in Oxford. I haven't been able to consult this copy to see if it is indeed a different edition or a bibliographical error. 
Jason, which was the source for the title woodcut of the 1511 and 1520 editions, can be considered a literary text of a similar kind to Seghelijn. But Roelant van den Dorpe's Chronicles, providing woodcuts for the editions of pre-1517, 1517 and around 1540, is not a romance but a chronicle, even though not all the histories presented by Van den Dorpe meet our standards of reliable history. Lastly, the image that Claes de Grave used for the 1517 edition was a biblical image. Its subject, the fall of a city (actually Jericho), was perhaps not completely at odds with some of the stories in Seghelijn, although the soldiers carrying the Ark of Covenant may have struck an odd note even to contemporary readers. One might expect that publishers would be willing to produce new woodcuts for a book such as Seghelijn whose popularity lasted throughout the first half of the sixteenth century. The opposite was the case. This reliance on older woodcuts was a characteristic Seghelijn shared with many narrative and historical texts in the sixteenth century.

To name just one example, the history of Margariete van Limborch has been the subject of a recent study by Rita Schlusemann. ${ }^{46}$ This romance, published as Een schoone historie va[n] margariete[n] va[n] limborch in 1516 by Willem Vorsterman in Antwerp, contains a large number of woodcuts. With the exception of the title illustration and the coat of arms on the verso, the book has 40 woodcuts, including a few repeats. Although some of them seem to have been made especially for this text, the majority had a history of previous use in older books, including books from the fifteenth century. An important source again was Roelant van den Dorpe's Chronicles from 1497, the same source from which several Seghelijn illustrations were borrowed. The double scene that was used in the pre-1517 and the 1517 editions of Seghelijn can also be found in Margariete. Vorsterman probably borrowed or purchased the woodblocks from Jan van Doesborch who had used many blocks from van den Dorpe to illustrate his own updated version of the Chronicles, Die alder excellenste cronyke, published in 1512. Other sources for the woodcuts in Margariete were a bit more recent, like the Vier Heemskinderen (1508). Apart from re-used images, Margariete contains a few copies after older illustrations to Godevaert van Boloen (1486) and Destructie van Jherusalem (c. 1505). Schlusemann's thorough research has demonstrated that there was a lively trade in woodblocks among printers and publishers, a subject that is far from exhausted. ${ }^{47}$

46 Rita Schlusemann, Schöne Historien. Niederländische Romane im deutschen Spätmittelalter und in der frühen Neuzeit. Berlin 2016.

47 Schlusemann (see note 46), p. 69-89. To the publishers mentioned by Schlusemann as former owners of some of the woodblocks (Jan van Doesborch, Jan Seversz) can be added Claes 
In general it can be said that woodcuts on the title-page of a book had a dual function. Firstly title-pages, including woodcuts, had an advertising function in a period when books were often sold without a cover. Whether purchased in a bookshop (often connected to a printer's workshop), on a market, or from a hawker, books were usually sold as a set of unbound quires. The title-page was thus an important feature of the book in transmitting information to the customer. In fact, the development of the title-page as such, and as the main source of information about the book, can be attributed to this practice of selling books without a prefabricated binding. ${ }^{48}$ Woodcuts supported this function. They could enhance the book's appeal and draw the customer's attention through their design.

Secondly, woodcuts on title-pages contributed to the identification of genres. The early sixteenth century saw an enormous increase in book production. Not only did the number of printers and publishers rise, they produced more books than their predecessors. ${ }^{49}$ The national and international book trade intensified and perhaps most of all, the position of authors changed. While the fifteenth century saw many existing texts from the manuscript age being printed and distributed, the sixteenth century produced an increasing number of new texts. These developments asked for a market strategy which did not yet exist for the printed book. With enlarged production, a greater variety of texts and a wider clientele, thanks to an improved literacy, publishers had to think of ways of reaching their public. Diversification was instrumental in this process. Specialisation became more common among publishers, especially towards the middle of the sixteenth century. Some publishers specialised in humanist texts, others in religious and devotional texts and others again in narrative literature. During the years between 1515 and 1540, the title-page plus woodcut developed in such a way that it became easy to recognise a humanist text, a devotional tract, a herbal or a narrative text at a glance. The discerning characteristic for this last category was that the woodcuts were often of a narrative nature, representing a scene from a story, and of a stylistically oldfashioned character. This was underlined through the use of older, fifteenth century images.

de Grave, owner of a wedding scene, used by him in Dat regime[n]t vanden huwelijcken staet (1512): Schlusemann p. 86 and 259, No. B 40.

48 See Margareth M. Smith, The Title-Page, its Early Development 1460-1510. New Castle, London 2000, passim but especially chapters one (p. 25-34) and six (p. 91-108); Rautenberg (see note 17), passim.

49 The USTC lists 2061 books printed in the Low Countries before 1501 (1473-1500), while a calculation for the period 1501 to 1530 results in 3624 books (retrieved December 2017). 
The use of older woodcuts in sixteenth century books has been described by, amongst others, Carsten-Peter Warncke and Christine Boßmeyer as an instance of the typological character of fifteenth and sixteenth century woodcuts. ${ }^{50} \mathrm{~A}$ woodcut of a battle could serve many goals. Its generic quality made it suitable to be used in different books, describing different battles. The same can be said of city-views or portraits. ${ }^{51}$ Nevertheless this is not the complete story. For example, Boßmeyer refers to the repeated use of the same woodcut of a city view in the Weltchronik of Hartmann Schedel (1490) for the portrayal of many different cities while at the same time the Weltchronik contains large woodcuts which have been specifically designed to illustrate one city only. ${ }^{52}$ Both tendencies thus existed side by side, the use of typological or generic images to cover a range of specific subjects as well as the use of increasingly 'naturalistic' images to portray the world. However, the stylistic characteristics of these images and their functionality have largely been ignored. Outmoded images were well suited to indicate the nature of the books they adorned. They visualised the ancient and traditional character of the texts that were often also emphasized in the textual elements on the title-pages. The practice of employing older, or older-looking, woodcuts was thus a conscious decision on the part of the publisher / printer, in order to characterise their texts. ${ }^{53}$

And this is exactly what the publishers of Seghelijn did. The generic character of the woodcuts they employed suited the text well, for a woodcut of the siege of a city could function in different contexts and be used for sieges from different times and places. Indeed this proved to be a distinguishing characteristic of much narrative literature in the sixteenth century. Apart from the already-mentioned Margariete, this can be demonstrated by other narrative texts as well, such as Die distructie van Troyen (Jan van Doesborch, 1508-1515), Hystorie van Olyvier van Castillen (Hendrick Eckert van Homberch, c. 1510) and Die historie van Peeter van Prove[n]cen (Willem Vorsterman, c. 1517). That this was not just a matter of the careless use of already available woodcuts, but

50 Carsten-Peter Warncke, Sprechende Bilder - sichtbare Worte. Das Bildverständnis in der frühen Neuzeit. Wiesbaden 1987, p. 64-80; Christine Boßmeyer, Visuelle Geschichte in den Zeichnungen und Holzschnitten zum "Weißkunig” Kaiser Maximilans I. 2 vols. Ostfildern 2015. Textband, p. 217-223.

51 Examples of this can be found in Warncke (see note 50) and Boßmeyer (see note 50).

52 Boßmeyer (see note 50), p. 217.

53 The development of the illustrated title-page in the sixteenth-century Low Countries and the function of the woodcut in the publisher's strategy is the subject of a study scheduled for publication in 2020. This will also contain a more extensive evaluation of the use of woodcuts in narrative texts. [For old-style title-pages, see also the article by Syrovy in the present volume, $\mathrm{p}$. 351-374. 
a conscious choice by the publisher, is demonstrated by the 1517 edition of Seghelijn from the printer's shop of Claes de Grave. Here he combined, on the title-page, a fifteenth-century woodcut with border pieces copied after a book printed by the trendsetting firm of Johann Froben. There can be little doubt that De Grave was fully aware of the impact the stylistically innovative design of Urs Graf's woodcuts would make in the Low Countries. His decision to include a much older woodcut must have been the result of his intention to characterise the genre of narrative literature with an image customers would recognise as typical for much narrative literature.

\section{Bibliography}

Boßmeyer, Christine, Visuelle Geschichte in den Zeichnungen und Holzschnitten zum “Weißkunig” Kaiser Maximilans I. 2 vols. Ostfildern 2015.

Claassens, G.H.M., 'Die kerstenwet stercken. Kruisvaartideologie en kritiek in de Seghelijn van Iherusalem'. In: TNTL 107 (1991), p. 235-273.

Claassens, G.H.M., 'Seghelijn van Jheruzalem'. In: Van Aiol tot de Zwaanridder. Personages uit de middeleeuwse verhaalkunst en hun voortleven in literatuur, theater en beeldende kunst. Ed. by W.P. Gerritsen A.G. van Melle. Nijmegen 1993, p. 299-300.

Claassens, G.H.M., 'Dat en is sonder reden niet. Over de zeven vragen van Seghelijn van Jherusalem'. In: Spiegel der Letteren 40 (1998), p. 25-54.

Claassens, G.H.M., 'Membra disiecta: excessief geweld in de ridderroman Seghelijn van Jherusalem'. In: Kabaal! Feest en strijd in de Nederlandse literatuur. Ed. by Elke Brems, An Faems and Eveline Vanfraussen. Leuven 2004, p. 25-55.

Conway, William Martin, The Woodcutters of the Netherlands in the Fifteenth Century. Cambridge 1884.

Debaene, Luc., De Nederlandse volksboeken. Ontstaan en geschiedenis van de Nederlandse prozaromans, gedrukt tussen 1475 en 1540. Antwerpen 1951.

Faems, An, 'Nu hoert, ghi heren, ende verstaet ende neemt exempel aen desen man. De functie van het vertellerscommentaar in Seghelijn van Jhersualem'. In: Millennium 15 (2001), p. 114-139.

Frank, Hieronymus, Oberrheinische Buchillustration, 2. Basler Buchillustration, 1500-1545. Basel 1984.

Franssen, Peter J.A., Tussen tekst en publiek. Jan van Doesborch, drukker-uitgever en literator te Antwerpen en Utrecht in de eerste helft van de zestiende eeuw. Amsterdam 1990.

Heurck, Emile van, Les livres populaires flamands. Antwerpen 1931.

Jonckbloet, W.J.A., Geschiedenis der Nederlandsche letterkunde. Vol. 1. Groningen 1868.

Kok, Ina, Woodcuts in Incunabula Printed in the Low Countries. 4 vols. Houten 2013.

Mann Phillips, Margaret, The Adages of Erasmus. A Study with Translations. Cambridge 1964. Nagler, G.K., Die Monogrammisten. 5 vols. Munich 1858-1879.

Rautenberg, Ursula, 'Die Entstehung und Entwicklung des Buchtitelblatts in der Inkunabelzeit in Deutschland, den Niederlanden und Venedig - Quantitative und qualitative Studien'. In: Archiv für Geschichte des Buchwesens 62 (2008), p. 1-105. 
Resoort, Rob J., 'Het raadsel van de rijmdrukken'. In: Nederlandse Letterkunde 3 (1998), p. 327-344.

Schlusemann, Rita, Schöne Historien. Niederländische Romane im deutschen Spätmittelalter und in der frühen Neuzeit. Berlin 2016.

Smith, Margareth M., The Title-Page, Its Early Development 1460-1510. New Castle, London 2000.

Verdam, Jacob (ed.), Seghelijn van Jherusalem naar het Berlijnsche handschrift en den ouden druk. Leiden 1878.

Warncke, Carsten-Peter, Sprechende Bilder - sichtbare Worte. Das Bildverständnis in der frühen Neuzeit. Wiesbaden 1987.

Wijer, Ingrid van de, Segheliin. Codicologische, bibliographische en tekstkritische studie en editie (diss. Leuven). 2 vols. Leuven 1983.

Wijer, Ingrid van de, 'Segheliin van Iherusalem, tekstoverlevering van een Middelnederlands ridderdicht'. In: Quaerendo 14 (1984), p. 273-303.

Wyn, Henrik van, Historische en letterkundige avondstonden. Amsterdam 1800. 